\title{
Effects of bile acids on proliferation and production of proteinase activity of Uronema marinum (Ciliophora: Scuticociliatida)
}

\author{
Hyoung Jun Kim ${ }^{1}$, Su Kyung Choi ${ }^{1}$, Seung Hyuk Choi ${ }^{1}$, Min Sun Kim ${ }^{1}$, \\ Sung Koo Kim ${ }^{2}$, Yoon Kwon Nam ${ }^{3}$, Ki Hong Kim ${ }^{1, *}$
}

${ }^{1}$ Department of Aquatic Life Medicine, ${ }^{2}$ Faculty of Food Science and Biotechnology, and ${ }^{3}$ Department of Aquaculture, Pukyong National University, Pusan 608-737, South Korea

\begin{abstract}
Little is known about the effects of bile acids in relation to infectivity on the biological characteristics of Uronema marinum, a serious opportunistic parasite of farmed olive flounder Paralichthys olivaceus. In this study, we examined the effects of bile acids on the proliferation of $U$. marinum and on proteinase production in vitro. Proliferation of $U$. marinum was significantly enhanced by lithocholic acid (LCA) at 30 and $60 \mu \mathrm{mol}$, and by chenodeoxycholic acid (CDCA) at $0.06 \mu \mathrm{mol}$. In contrast, a significant decrease in proliferation was observed with cholic acid (CA) at 30 and $60 \mu \mathrm{mol}$, and with deoxycholic acid (DCA) at all amounts used. Proteinase production from live U. marinum was significantly increased by LCA, whereas CA significantly decreased proteinase production. CDCA and DCA had no effect on proteinase production. Although the types and concentrations of bile acids in the faeces of olive flounder are not known, the present results suggest that bile acids in the culturing water might influence the proliferation and production of proteinases in U. marinum, resulting in an increased possibility of scuticociliatosis in olive flounder farms.
\end{abstract}

KEY WORDS: Uronema marinum $\cdot$ Bile acids $\cdot$ Proliferation $\cdot$ Proteases

\section{INTRODUCTION}

Uronema marinum is a facultative scuticociliate responsible for an increasing number of serious infections in farmed olive flounder Paralichthys olivaceus in Korea (Jee et al. 2001). The ciliate is characterized by its high potential for systemically invading and destroying fish tissues leading to significant mortalities of the host. However, the parasite and the host factors that determine the onset of disease remain undetermined. Several researchers have assumed that immunosuppression by various stressors on the fish including handling, environmental pollution, inappropriate diet, and wounds could make it possible for scuticociliates to cross the immunological barriers of fish (Cheung et al. 1980, Dragesco et al. 1995, Munday et al. 1997, Sterud et al. 2000, Iglesias et al. 2003). However, it cannot be excluded that the strengthening of scuticociliates infection potential is due to certain factors present in fish culture tanks and might be involved in infection by scuticociliates.

In the pathogenesis of parasitic diseases, proteinases have been shown to play important roles in the facilitation of host tissue invasion, digestion of host proteins, and protection against immunological attacks by the host (McKerrow 1989, McKerrow et al. 1993). The roles of proteinases in the virulence of Uronema marinum are unclear, but secretion of proteinases is thought to be necessary to break down protein barriers in the host. In addition, high density of scuticociliates in culturing tanks would increase the infection pressure.

Bile acids are steroid metabolites of cholesterol, which function as trophic factors for the gut epithelium and as detergents for the absorption of cholesterol and fat-soluble vitamins. In humans, the primary bile acids, cholic and chenodeoxycholic acids, are synthesized in the liver and are excreted into the duodenum, where they facilitate absorption of dietary lipids. Most of 
these bile acids are reabsorbed in the intestine. However, a small quantity remains unabsorbed and passes into the colon, where it is converted to secondary bile acids, deoxycholic and lithocholic acids, by enteric bacteria. Fish release bile acids into the surrounding water mainly through faeces (Zhang et al. 2001), and it has been suggested that the excreted bile acids play a role as chemical signals which can induce behavioral responses in fish (Stabell 1987, Sola \& Tosi 1993, Li et al. 1995).

Studies on human colorectal cancer have shown that bile acids stimulate cell proliferation and invasion of carcinoma cells (Debruyne et al. 2001). Little is known about the effects of bile acids on the biological characteristics of Uronema marinum in relation to infectivity. In this study, we examined the effects of bile acids on the proliferation of $U$. marinum and on proteinase production in vitro.

\section{MATERIALS AND METHODS}

Culture of Uronema marinum. Cells of $U$. marinium isolated from the brain of infected olive flounders Paralichthys olivaceus in the logarithmic phase of growth were cultured in filtered and autoclaved seawater containing $0.2 \%$ yeast extract at $25^{\circ} \mathrm{C}$.

Effect of bile acids on the proliferation of Uronema marinum. The bile acids cholic acid (CA), chenodeoxycholic acid (CDCA), deoxycholic acid (DCA) and lithocholic acid (LCA) were obtained from Sigma. The ciliate count was $10^{2}$ in $100 \mu \mathrm{l}$ of total volume at the start of the experiments. The ciliates were held in 96-well flat-bottomed microplates, and 5 wells comprised 1 group. The ciliates were exposed to 0 (control), 0.06 , $0.6,6,30$, and $60 \mu \mathrm{mol}$ of each kind of bile acid, and were cultivated in a humidified chamber at $25^{\circ} \mathrm{C}$. After $48 \mathrm{~h}$, the ciliates were fixed in $4 \%$ formaldehyde, and the number of cells was determined with a light microscope and Neubauer haemocytometer.

Effect of bile acids on proteinase activity of Uronema marinum. The proteolytic activity of the live $U$. marinum was detected by incubating $5 \times 10^{4}$ cells of the ciliate in $10 \mu \mathrm{l}$ filtered seawater. To this was added $10 \mu \mathrm{l} \mathrm{of} 10 \mu \mathrm{g} \mathrm{ml}^{-1}$ of fluorescein isothiocynate (FITC)casein (Sigma) and $180 \mu \mathrm{l}$ of filtered seawater ( $\mathrm{pH} 7.0$ ) containing $60 \mu \mathrm{mol}$ of each bile acid in a black 96-well plate (Greiner Bio-One) at $25^{\circ} \mathrm{C}$. Wells not supplemented with any bile acids were used as controls. In addition, wells with FITC-casein plus each bile acid without the ciliate were used to confirm whether bile acids themselves influence the fluorescence polarization (FP) values, and wells containing only $200 \mu \mathrm{l}$ of filtered seawater were designated as blanks. The fluorescence polarization was measured in a Polarion instrument (TECAN Austria). The excitation wavelength and the emission wavelengths were 485 and $535 \mathrm{~nm}$, respectively. All assays were done in 5 replicates. Readings were automatically recorded at 30,60 , 90, 150, and $180 \mathrm{~min}$ in millipolarization units (mP).

Statistics. The Mann-Whitney test was used to compare each amount of bile acid with the controls, i.e. ciliates cultured without bile acids. Differences were considered significant when $\mathrm{p}<0.05$.

\section{RESULTS}

\section{Effect of bile acids on Uronema marinum proliferation}

Proliferation of Uronema marinum was significantly enhanced by LCA at 30 and $60 \mu \mathrm{mol}$, and by CDCA at $0.06 \mu \mathrm{mol}$. In contrast, a significant decrease in proliferation was observed with CA at 30 and $60 \mu \mathrm{mol}$, and with DCA at all amounts used (Fig. 1).

\section{Effect of bile acids on the production of proteinase activity}

The production of proteinase activity from live Uronema marinum was significantly increased by LCA, whereas CA significantly decreased proteinase activity. CDCA and DCA had no effect on proteinase activity (Fig. 2).

\section{DISCUSSION}

The present results suggest that specific bile acids can exert potent effects on Uronema marinum proliferation. The proliferation was significantly induced by LCA at 30 and $60 \mu \mathrm{mol}$ and by CDCA at $0.06 \mu \mathrm{mol}$. The effects of bile acids on cell proliferation have been well demonstrated from researches in human colon cancer (Debruyne et al. 2001). Raised levels of secondary bile acids have been reported in patients with adenomatous polyps and colon cancer (Reddy \& Wynder 1977. Imray et al. 1992). Although the mechanism of this tumor promoter activity is unknown, it has been suggested that bile acids act by modifying intracellular signaling and gene expression, perhaps by altering the activity of Protein Kinase C (PKC) (Huang et al. 1992, Pongracz et al. 1995, Hirano et al. 1996, Rao et al. 1997). PKC plays a key role in the regulation of cellular processes including growth, differentiation, tumor promotion, and apoptosis (Blobe et al. 1994). Studies have shown that bile acids activate PKC in both normal colonic epithelial cells and in colon tumor cell lines 
(Craven et al. 1987, Huang et al. 1992). Ciliates have well-developed signal cascade mechanisms (Csaba 1985, 1994, Kovács \& Csaba 1995, Christensen et al.

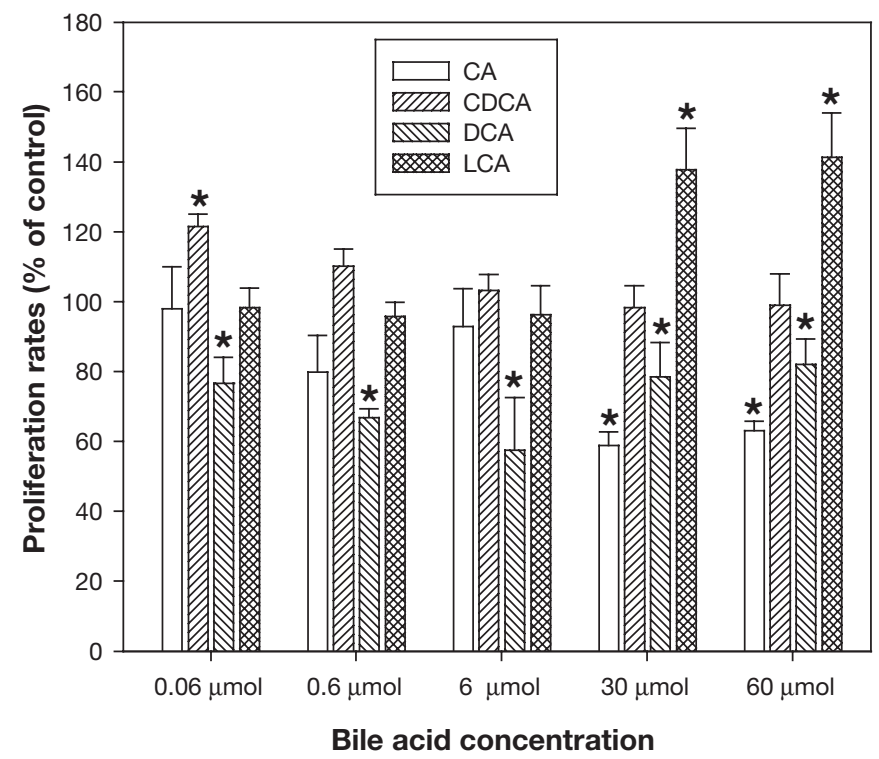

Fig. 1. Uronema marinum. Effect of cholic acid (CA), chenodeoxycholic acid (CDCA), deoxycholic acid (DCA) and lithocholic acid (LCA) on the proliferation of Uronema marinum related to the control as $100 \%$. Points represent mean values \pm standard deviation. $\left({ }^{*} \mathrm{p}<0.05\right)$

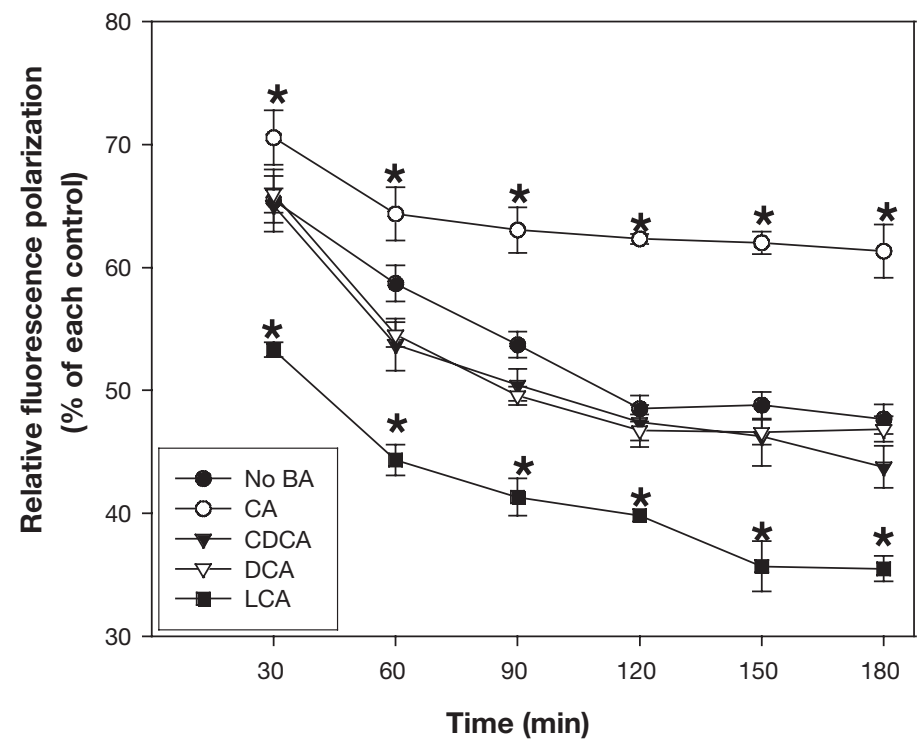

Fig. 2. Uronema marinum. Effect of cholic acid (CA), chenodeoxycholic acid (CDCA), deoxycholic acid (DCA) and lithocholic acid (LCA) on the production of proteinase activity of $U$. marinum related to each control as $100 \%$. Proteinase activity was measured by fluorescence polarization, and was detected using FITC-casein as a substrate at $\mathrm{pH}$ 7. Points represent mean values \pm standard deviation. (No $\mathrm{BA}=$ not supplemented with any bile acids; ${ }^{*} \mathrm{p}<0.05$ )
1998). Increased survival and proliferation of Tetrahymena thermophila by treatment with phorbol 12myristate 13-actate (PMA), a direct activator of PKC, has been reported (Straarup et al. 1997). Therefore, activation of PKC and modification of signal transduction appear to be an aspect of the effect of bile acids in the proliferation of $U$. marinum. Epidemiological studies in humans have associated the development of colorectal cancer with elevations in fecal bile acid concentration, particularly LCA (Hill 1991a,b). It has been reported that the ratio of LCA to DCA is 2-fold greater in persons with colon cancer compared to controls (Owen et al. 1986). Interestingly, in the present study, the proliferation of $U$. marinum was significantly increased by LCA but significantly decreased by DCA.

The results presented in this paper suggest that bile acids can modulate the production of proteinase activity of Uronema marinum. LCA significantly increased proteinase activity, whereas CA significantly decreased it. It has been reported that treatment of human colorectal cancer CaCo-2 cells by LCA resulted in an enhanced secretion of Gelatinase A or Matrix Metalloproteinase 2 (MMP-2) (Halvorsen et al. 2000). Proteolytic degradation of extracellular matrix (ECM) components by MMPs is involved in both physiological and pathological processes such as development, tissue remodeling, inflammation, tumor cell invasion, and tumor metastasis (Woessner 2002). The positive effect of PKC activation on the secretion of MMPs has been well demonstrated in cancer cell lines (Williger et al. 1999, Shum et al. 2002). Thus activation of PKC by LCA might be a cause of the increase of $U$. marinum proteinase activity in the present study.

Limited information is available on the types and concentrations of bile acids released by fish into the surrounding water. Zhang et al. (2001) reported that lake char Salvelinus namaycushi released $4 \mathrm{nmol}$ $\mathrm{min}^{-1}$ bile acids per $\mathrm{kg}$ of body weight into the surrounding water, and faeces contained a total of

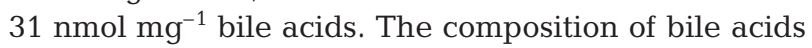
in faeces was similar to that in bile, containing over $80 \%$ taurocholic acid, taurochenodeoxycholic acid, and a trace of taurolithocholic acid. Although the types and concentrations of bile acids in the faeces of olive flounder are not known, the present results suggest that bile acids in the culturing water might influence the proliferation and proteinase activity of Uronema marinum, resulting in the increased possibility of scuticociliatosis in olive flounder farms. Further research into the types and concentrations of bile acids in olive flounder faeces, and their effects on the biological characteristics of $U$. marinum may provide us with a better understanding of the causes of scuticociliatosis. 
Acknowledgements. This study was supported by a grant from the Ministry of Maritime Affairs and Fisheries, Republic of Korea.

\section{LITERATURE CITED}

Blobe GC, Obeid LM, Hannun YA (1994) Regulation of protein kinase $\mathrm{C}$ and role in cancer biology. Cancer Metastasis Rev 13:411-431

Cheung PJ, Nigrelli RF, Ruggieri GD (1980) Studies on the morphology of Uronema marinum Dujardin (Ciliatea: Uronematidae) with a description of the histopathology of the infection in marine fishes. J Fish Dis 3:295-303

Christensen ST, Chemnitz J, Straarup EM, Kristiansen K, Wheatley DN, Rasmussen L (1998) Staurosporine-induced cell death in Tetrahymena thermophila has mixed characteristics of both apoptotic and autophagic degeneration. Cell Biol Int 22:591-598

Craven PA, Pfanstiel J, DeRubertis FR (1987) Role of activation of protein kinase $\mathrm{C}$ in the stimulation of colonic epithelial proliferation and reactive oxygen formation by bile acids. J Clin Invest 79:532-541

Csaba G (1985) The unicellular Tetrahymena as a model cell for receptor research. Int Rev Cytol 95:327-377

Csaba G (1994) Phylogeny and ontogeny of chemical signaling: origin and development of hormone receptors. Int Rev Cytol 155:1-48

Debruyne PR, Bruyneel EA, Li X, Zimber A, Gespach C, Mareel MM (2001) The role of bile acids in carcinogenesis. Mutat Res 480/481:359-369

Dragesco A, Dragesco J, Coste F, Gasc C, Romestand B, Raymond J, Bouix G (1995) Philasterides dicentrarchi, n. sp., (Ciliophora, Scuticociliatida), a histophagous opportunistic parasite of Dicentrarchus labrax (Linnaeus, 1758), a reared marine fish. Eur J Protistol 31:327-340

Halvorsen B, Staff AC, Ligaarden S, Prydz K, Kolset SO (2000) Lithocholic acid and sulphated lithocholic acid differ in the ability to promote matrix metalloproteinase secretion in the human colon cancer cell line CaCo-2. Biochem J 349: 189-193

Hill MJ (1991a) Bile acids and colorectal cancer: hypothesis. Eur J Cancer Prev 1(Suppl 2):69-74

Hill MJ (1991b) The ratio of lithocholic to deoxycholic acid in faeces: a risk factor in colorectal carcinogenesis. Eur J Cancer Prev 1(Suppl 2):75-78

Hirano F, Tanaka H, Makino Y, Okamoto K, Hiramoto M, Handa H, Makino I (1996) Induction of the transcription factor AP-1 in cultured human colon adenocarcinoma cells following exposure to bile acids. Carcinogenesis 17: $427-433$

Huang XP, Fan XT, Desjeux JF, Castagna M (1992) Bile acids, non-phorbol-ester-type tumor promoters, stimulate the phosphorylation of protein kinase $\mathrm{C}$ substrates in human platelets and colon cell line HT29. Int J Cancer 52: 444-450

Iglesias R, Paramá A, Álvarez MF, Leiro J, Ubeira FM, Sanmartín ML (2003) Philasterides dicentrarchi (Ciliophora: Scuticociliatida) expresses surface immobilization antigens that probably induce protective immune responses in turbot. Parasitology 126:125-134

Imray CHE, Radley S, Davis A, Barker G and 5 others (1992) Fecal unconjugated bile acids in patients with colorectal

Editorial responsibility: Wolfgang Körting,

Hannover, Germany cancer or polyps. Gut 33:1239-1245

Jee BY, Kim YC, Park MS (2001) Morphology and biology of parasite responsible for scuticociliatosis of cultured olive flounder Paralichthys olivaceus. Dis Aquat Org 47:49-55

Kovács P, Csaba G (1995) Effect of phorbol 12-myristate 13-acetate (PMA) on the phosphoinositol (PI) system in Tetrahymena: study of the ${ }^{32} \mathrm{P}$ incorporation and breakdown of phospholipids. Cell Biochem Funct 13:85-89

Li W, Sorensen PW, Gallaher DD (1995) The olfactory system of migratory adult sea lamprey (Petromyzon marinus) is specifically and acutely sensitive to unique bile acids released by conspecific larvae. J Gen Physiol 105:569-587

McKerrow JH (1989) Minireview: parasite proteases. Expl Parasitol 68:111-115

McKerrow JH, Sun E, Rosenthal PJ, Bouvier J (1993) The proteases and pathogenicity of parasitic protozoa. Annu Rev Microbiol 47:821-853

Munday BL, O'Donoghue PJ, Watts M, Rough K, Hawkesford $\mathrm{T}$ (1997) Fatal encephalitis due to the scuticociliate Uronema nigricans in sea-caged, southern bluefin tuna Thunnus maccoyii. Dis Aquat Org 30:17-25

Owen RW, Henly PJ, Thompson MH, Hill MJ (1986) Steroids and cancer: faecal bile acid screening for early detection of cancer risk. J Steroid Biochem 24:391-394

Pongracz J, Clark P, Neoptolemos JP, Lord JM (1995) Expression of protein kinase $\mathrm{C}$ isoenzymes in colorectal cancer tissue and their differential activation by different bile acids. Int J Cancer 61:35-39

Rao YP, Stravitz RT, Vlahcevic ZR, Gurley EC, Sando JJ, Hylemon PB (1997) Activation of protein kinase C $\alpha$ and $\delta$ by bile acids: correlation with bile acid structure and diacylglycerol formation. J Lipid Res 38:2446-2454

Reddy BS, Wynder EL (1977) Faecal bile acids and neutral sterols in colon cancer patients and patients with adenomatous polyps. Cancer 39:2533-2539

Shum JKS, Melendez JA, Jeffrey JJ (2002) Serotonin-induced MMP-13 production is mediated via phospholipase $\mathrm{C}$, protein kinase $C$, and ERK1/2 in rat uterine smooth muscle cells. J Biol Chem 277:42830-42840

Sola C, Tosi L (1993) Bile acids and taurine as chemical stimuli for glass eels, Anguilla anguilla: a behavioral study. Environ Biol Fishes 37:197-204

Stabell OB (1987) Intraspecific pheromone discrimination and substrate marking by Atlantic salmon parr. J Chem Ecol 13:1625-1643

Sterud E, Hansen MK, Mo TA (2000) Systemic infection with Uronema-like ciliates in farmed turbot, Scophtalmus maximus (L.). J Fish Dis 23:33-37

Straarup EM, Schousboe P, Hansen HQ, Kristiansen K, Hoffmann EK, Rasmussen L, Christensen ST (1997) Effects of protein kinase $\mathrm{C}$ activators and staurosporine on protein kinase activity, cell survival, and proliferation in Tetrahymena thermophila. Microbios 91:181-190

Williger BT, Ho WT, Exton JH (1999) Phospholipase D mediates matrix metalloproteinase- 9 secretion in phorbol esterstimulated human fibrosarcoma cells. J Biol Chem 274 : 735-738

Woessner JF Jr (2002) MMPs and TIMPs - an historical perspective. Mol Biotechnol 22:33-49

Zhang C, Brown SB, Hara TJ (2001) Biochemical and physiological evidence that bile acids produced and released by lake char (Salvelinus namaycush) function as chemical signals. J Comp Physiol B 171:161-171

Submitted: February 9, 2004; Accepted: July 16, 2004

Proofs received from author(s): November 2, 2004 